\title{
Assessing Influence of Ozone in Tomato Seed Dormancy Alleviation
}

\author{
N. Sudhakar ${ }^{1 *}$, D. Nagendra-Prasad ${ }^{2}$, N. Mohan ${ }^{2}$, Bradford Hill ${ }^{3}$, M. Gunasekaran ${ }^{3}$, K. Murugesan ${ }^{2}$ \\ ${ }^{1}$ Department of Microbiology, Sengunthar Arts and Science College, Tiruchengode, India; ${ }^{2}$ Center for Advanced Studies in Botany, \\ University of Madras, Guindy Campus, Chennai, India; ${ }^{3}$ Department of Biology, Fisk University, Nashville, USA. \\ Email: "nadesansudhakar@yahoo.co.in
}

Received May 20 $0^{\text {th }}, 2011$; revised June 29 $9^{\text {th }}, 2011$; accepted July $18^{\text {th }}, 2011$.

\begin{abstract}
The study was made on the role of ozone $\left(\mathrm{O}_{3}\right)$ gas treatment on seeds of Lycopersicon esculentum $\mathrm{cv}$. PKM1 (tomato) to release dormancy in advance. The experimental conditions followed a complete factorial design with 3 independent factors, i.e. A faster start of germination in $T_{2}$ treatment (98\% - 99\%) was observed than in other treatments $\left(T_{1}, T_{3}\right.$ and $T_{4}$ ) compared to control seeds by measuring seedling growth rate on $5^{\text {th }}$ day after treatment. Nevertheless a too long and high concentration of $\mathrm{O}_{3}$ treatment seemed to be penalizing on germination rate whereas low $\mathrm{O}_{3}$ concentration $\left(T_{2}\right)$ for a moderate time interval (20 $\mathrm{min}$ ) seemed to be most beneficial. The treated seeds were stored, checked 1, 3, 6 months later and found that, the seeds have retained their accelerated germination efficiency. In particular, $1 T_{2}(1$ month storage), $3 T_{2}$ (3 month storage) had maximum germination rate among all the stored treated seeds, but $6 T_{2}(6$ month storage) didn't show sustained germination acceleration efficiency. Therefore, it was found that when time prolongs, $\mathrm{O}_{3}$ treatment loss its effect steadily and the germination efficiency of all the treatments are more or less same at six months after treatment. It is hypothesized that the application of $\mathrm{O}_{3}$ acts as an important phenomenon in accelerating seed germination by breaking the dormancy in advance which is associated with reduced level of $A B A$ in $\mathrm{O}_{3}$ treated seeds.
\end{abstract}

Keywords: Abscissic Acid, Germination, Ozone, Tomato Seed

\section{Introduction}

Germination is the process which leads to elongation of the embryonic axis from a seed, allowing subsequent seedling emergence. Seed dormancy is defined as the failure of an intact viable seed to complete germination under favorable conditions and is controlled by several environmental factors, such as light, temperature and the duration of seed storage (after ripening) [1,2]. Dormancy may be related to the embryo itself or to its surrounding structures i.e., seed coat which lead to distinguish several classes of dormancy [3]. Dormancy and germination are determined by the co-action of the growth potential of the embryo and the restraints imposed by the tissues surrounding it. It is known that, when used in the natural state, seeds for agricultural production suffer from a certain number of deficiencies, giving rise in particular to a small germination percentage, to growth defects, and to pathology specific thereof.

Various studies have been done documenting the exogenous treatment of seeds to break seed dormancy. Scarification is the weakening of seed coats by mechani- cal abrasions or chemical treatments. Mechanically, the abrasions are caused by machine threshing, or chemical treatments. Chemically, the seeds are treated with chemicals like potassium nitrate, thiourea, ethylene, chlorohydrine to make the seed coats soft and weak. In addition the positive effects of oxidative stress on germination have also been documented $[4,5]$.

The biological effects of ozone $\left(\mathrm{O}_{3}\right)$ on plants have been studied for more than 50 years. Plants have evolved a complex of defence response mechanisms to respond various environmental stresses from morphological, biochemical and physiological changes triggered by $\mathrm{O}_{3}$ [6-8]. Ozone is a strong oxidant and it is an effective disinfectant because it has the unique ability to destroy toxic or noxious industrial impurities and inactivates biological (viral and bacterial) contaminants through the oxidation of double bonds [9]. In seeds, reactive oxygen species (ROS) production has been considered for a long time as being very harmful, since the works dealing with ROS were mainly focused on seed ageing or seed desiccation, two stressful situations which often lead to oxidative 
stress [10]. Numerous recent works have nevertheless brought new lines of evidence showing that the role of ROS in seeds is not as unfavourable as it was considered previously [11].

ROS derivate from the reduction of oxygen which gives rise to superoxide $\left(\mathrm{O}_{2}^{-}\right)$, hydrogen peroxide $\left(\mathrm{H}_{2} \mathrm{O}_{2}\right)$, hydroxyl radical $(\mathrm{HO})$ and singlet oxygen $\left(\mathrm{O}_{2}\right]$. ROS been playing a role in cellular signaling, and these compounds could facilitate the shift from a dormant to a nondormant status in seeds [10]. Indeed, it is known that ROS can accumulate during seed storage in the dry state, as previously mentioned [12-14]. There was a clear cut relationship between seed dormancy alleviation and accumulation of ROS and peroxidation products in cells of embryonic axes, thus suggesting that ROS might play a role of signal in dormancy alleviation $[15,16]$. Several reviews have described the signalling roles of ROS in plants and their role in plant growth and development is well documented.

Therefore, aim of the present study is to examine the influence of $\mathrm{O}_{3}$ gas generation in eliciting ROS on tomato seeds to release dormancy in advance and the grounds for acceleration of germination will be deliberated.

\section{Materials and Methods}

\subsection{Ozone Generation}

Ozone gas was generated by passing dry oxygen gas through a corona discharge type $\mathrm{O}_{3}$ generator ( $\mathrm{V}$ can Network model M221), passed through a concentration equalization tank, and bubbled into the deionized water with a glass diffuser. The $\mathrm{O}_{3}$ gas output was estimated with an $\mathrm{O}_{3}$ analyzer kit (BMT 961).

\subsection{Seed Material}

Lycopersicon esculentum cv. PKM1 (tomato) seeds isolated from ripe fruits were used for the study. All the seeds used for the study were incubated in $1 \% \mathrm{HCl}$ for 1 $\mathrm{h}$ to remove the remnants of the mucilaginous locular tissue. Subsequently, the seeds were rinsed with tap water, dried at room temperature, and stored in closed plastic container in a refrigerator at $7^{\circ} \mathrm{C}$ until use.

\subsection{Seed Treatments}

In order to investigate the effects of $\mathrm{O}_{3}$ on germination, the seeds were sterilized in the laboratory using Sodium Hypochlorite of $7 \%$ for $1 \mathrm{hr}$ and washed three times with sterile distilled water. Tomato seeds were humidified in a plastic flask and distilled water was added, until all the seeds were get completely immersed. For each treatment fifty seeds were used. Seeds were introduced in the reactor and treated with different $\mathrm{O}_{3}$ concentration, $\mathrm{T}_{1}=0.001$ grams per gram $\left(\mathrm{g} \mathrm{O}_{3} \mathrm{~g}^{-1}\right)$ of seeds, $\mathrm{T}_{2}=0.01 \mathrm{~g} \mathrm{O}_{3} \mathrm{~g}^{-1}$ seeds, $\mathrm{T}_{3}=0.1 \mathrm{~g} \mathrm{O}_{3} \mathrm{~g}^{-1}$ seeds and $\mathrm{T}_{4}=1 \mathrm{~g} \mathrm{O}_{3} \mathrm{~g}^{-1}$ seeds were performed in the sterilized-diffusers for a various time duration of 10, 20 and 30 mins respectively. While for the control (C) tomato seeds, charcoal filtered air (Cl-F) were passed. After treatment, seed were removed from the reactor, dried at room temperature, and stored in closed plastic container in a refrigerator at $7^{\circ} \mathrm{C}$ until use.

\subsection{Germination Test}

The germination tests were performed using treated seeds, by giving four different periods of rest time before germination test, i.e. 1) Germination test performed immediately after treatment (referred to as $\mathrm{T}_{1}, \mathrm{~T}_{2}, \mathrm{~T}_{3}$ and $\mathrm{T}_{4}$ seeds); 2) One month after treatment (referred to as $1 \mathrm{~T}_{1}$, $1 \mathrm{~T}_{2}, 1 \mathrm{~T}_{3}$ and $1 \mathrm{~T}_{4}$ seeds); 3) Three months after treatment (referred to as $3 \mathrm{~T}_{1}, 3 \mathrm{~T}_{2}, 3 \mathrm{~T}_{3}$ and $3 \mathrm{~T}_{4}$ seeds), 4) Six months after treatment (referred to as $6 \mathrm{~T}_{1}, 6 \mathrm{~T}_{2}, 6 \mathrm{~T}_{3}$ and $6 \mathrm{~T}_{4}$ seeds). All the seeds including control seeds were sown in Petri dishes on one layer of filter paper (Whatmann No.1) moistened with $1.5 \mathrm{~mL}$ of $0.25 \mathrm{mg} \cdot \mathrm{L}^{-1}$ thiomersal to prevent fungal growth, without growth regulators or osmotic material. The Petri dishes were sealed with Parafilm to ensure closed-system models. All the plates were placed in closed plastic boxes and incubated at $26^{\circ} \mathrm{C} \pm 1{ }^{\circ} \mathrm{C}$ in the dark unless otherwise mentioned. In experiments with intact seeds, visible radicle protrusion was used as the criterion for germination unless mentioned otherwise [17]. These experimental conditions followed a complete factorial design with 3 independent factors, i.e. $\mathrm{O}_{3}$ concentration, treatment duration, and rest time before germination.

\subsection{ABA Determinations}

Quantitative determinations of endogenous ABA were performed according to techniques described by [18] using Gas chromatograph equipped with an electron capture detector. Recovery was determined with the use of ("4C) ABA that was added to the first extraction medium. It was shown to be at least $95 \%$.

\section{Results and Discussion}

Seed dormancy and germination are very complex phenomena which involve tightly controlled signalling pathways and molecular regulations. Seed germination is sensitive to both endogenous plant growth regulators and environmental factors. Although ROS have been widely considered as detrimental to seeds, recent advances in plant physiology signalling pathways has lead to reconsider their role [19]. ROS accumulation can therefore be also beneficial for seed germination and seedling growth by regulating cellular growth, ensuring a protection against pathogens or controlling the cell redox status. ROS 
probably also act as a positive signal in seed dormancy release. They interact with abscisic acid and gibberellins transduction pathway and are likely to control numerous transcription factors and properties of specific protein through their carbonylation [19].

Reports have shown that the transition from a quiescent seed to a metabolically active organism is associated with ROS generation, suggesting that it is a widespread phenomenon. Production of hydrogen peroxide has been demonstrated at the early imbibition period of tomato seeds [20]. Nitric oxide, hydroxyl radicals and superoxide radicals also accumulate during the germination of seeds of various species [21,22]. However, the external sources of ROS production and application methods are poorly documented. Therefore we made an attempt to demonstrate the influence of $\mathrm{O}_{3}$ in generation of ROS in accelerating germination in tomato seeds.

When different concentrations of $\mathrm{O}_{3}\left(\mathrm{~T}_{1}, \mathrm{~T}_{2}, \mathrm{~T}_{3}\right.$ and $\left.\mathrm{T}_{4}\right)$ passed to tomato seeds and immediately tested for the germination efficiency of treatments, although germination was noticed in all treatments within 5 days, on the whole maximum frequency of germination of tomato seeds were observed in the $20 \mathrm{~min} \mathrm{O}_{3}$ treatment than 10 and $30 \mathrm{~min}$ treatment. Therefore, hereafter results are discussed only about the 20 min $\mathrm{O}_{3}$ treatment, unless otherwise mentioned. Treated tomato seeds resulted in a faster germination rate vs. control samples. This early germination start led to a larger number of germinated seeds with longer roots at $5^{\text {th }}$ day. A faster start of germination was observed in $0 \mathrm{~T}_{1}, 0 \mathrm{~T}_{2}$ and $0 \mathrm{~T}_{3}$ ozone treated samples, whereas in $0 \mathrm{~T}_{4}$ doesn't. The germination of tomato seeds after treatments (before storage) were $0 \mathrm{~T}_{1}=$ $86 \%, 0 \mathrm{~T}_{2}=97 \%$ and $0 \mathrm{~T}_{3}=78 \%, 0 \mathrm{~T}_{4}=44 \%$ but for control (0C) 72 percentage germination was obtained (Table 1). Comparing to Control seeds, germination \% is relatively higher in $0 \mathrm{~T}_{2}=26 \%$, followed by $0 \mathrm{~T}_{1}=16 \%$ and $0 \mathrm{~T}_{3}=8 \%$. But, $0 \mathrm{~T}_{4}$ treatment shows $40 \%$ reduced germination than the control seeds. Nevertheless, too long an $\mathrm{O}_{3}$ treatment seemed to be unfavorable for seed growth, whereas a short one seemed to be most beneficial. The $\mathrm{O}_{3}$ treatment oxidizes the seeds and therefore, germination efficiency of the seeds decreased as the concentration $\left(0 \mathrm{~T}_{4}=40 \%\right)$ and treatment duration $(30 \mathrm{~min})$ of $\mathrm{O}_{3}$ increased (Table 1). Tests performed on seeds of tomato, representative of major existing families, have shown that $\mathrm{O}_{3}$ treatment without an additional agent serves to significantly improve the germination rate of the treated seeds.

Table 1. Effect of ozone treatments on germination of mature tomato seeds based on 3 independent factors, i.e. Ozone concentration, treatment duration, and rest time before germination.

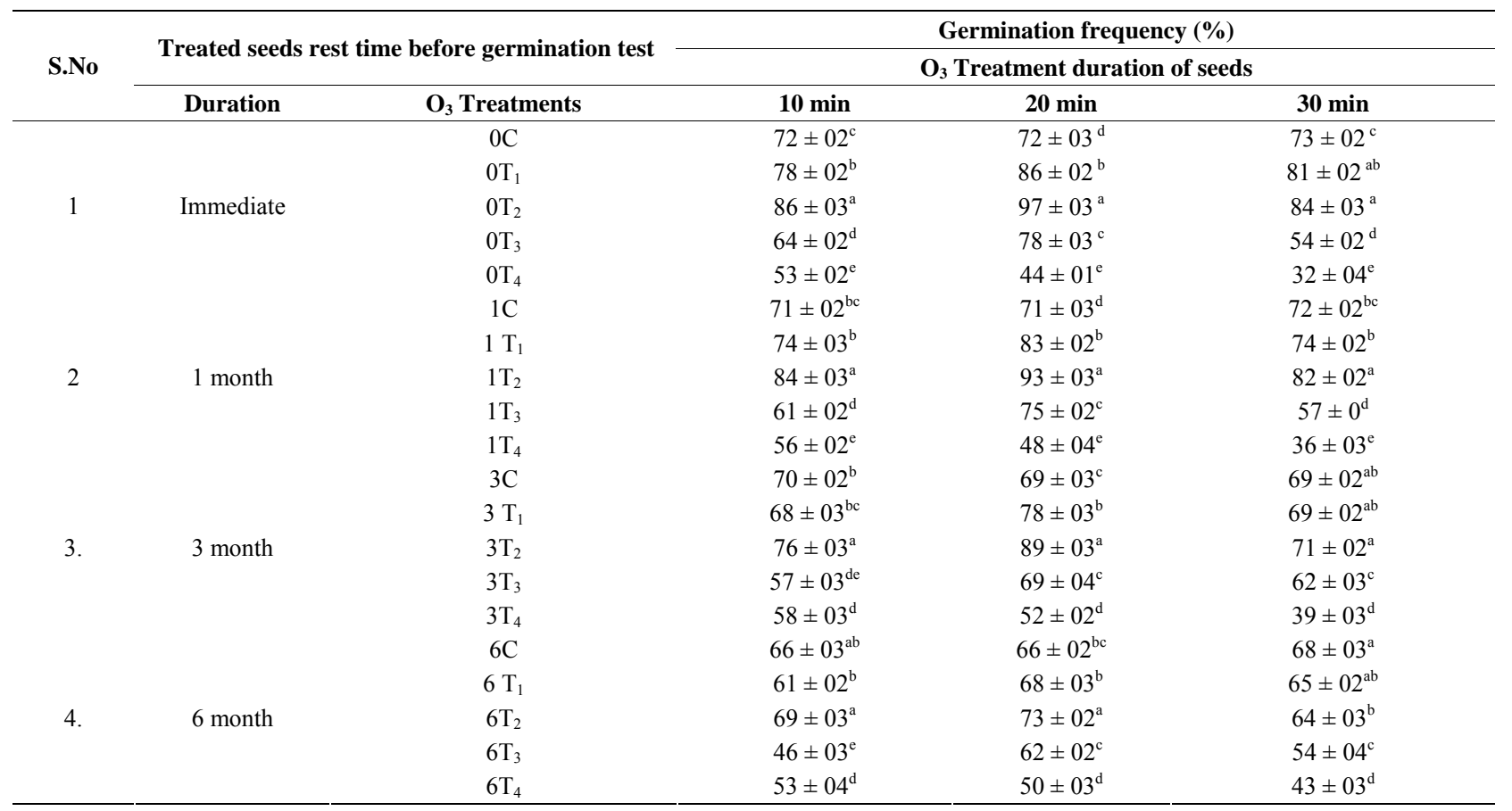

Each value is the mean of three experiments with ten replications each $(n=3)$. Statistically the means of the three experiments were not significantly different $(P<0.05)$. Means in the same column of respective S.No. with different letters are significantly different at $P<0.05$ in accordance with Fisher's least significant difference test. $\mathrm{T}_{1}=0.001 \mathrm{~g} \mathrm{O}_{3} \mathrm{~g}^{-1}$ seeds, $\mathrm{T}_{2}=0.01 \mathrm{~g} \mathrm{O}_{3} \mathrm{~g}^{-1}$ seeds, $\mathrm{T}_{3}=0.1 \mathrm{~g} \mathrm{O}_{3} \mathrm{~g}^{-1} \mathrm{seeds}$ and $\mathrm{T}_{4}=1 \mathrm{~g} \mathrm{O}_{3} \mathrm{~g}^{-1}$ seeds were performed in the sterilized-diffusers for a time duration of 10,20 and $30 \mathrm{~min}$. While for the control (C) tomato seeds, charcoal filtered air (Cl-F) were passed. Seeds were given dif-

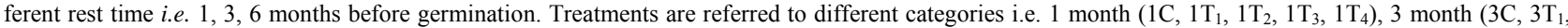
$\left.3 \mathrm{~T}_{2}, 3 \mathrm{~T}_{3}, 3 \mathrm{~T}_{4}\right)$ and 6 month $\left(6 \mathrm{C}, 6 \mathrm{~T}_{1}, 6 \mathrm{~T}_{2}, 6 \mathrm{~T}_{3}, 6 \mathrm{~T}_{4}\right)$ respectively. 
In order to check, whether $\mathrm{O}_{3}$ treated stored seeds retain the accelerated germination efficiency, it was checked and found that, all the $\mathrm{T}_{2}$ seeds, i.e. $1 \mathrm{~T}_{2}, 3 \mathrm{~T}_{2}$ and $6 \mathrm{~T}_{2}$ had maximum germination rate compared to other stored seeds $\left(T_{1}, T_{3}, T_{4}\right.$ seeds). Among the $T_{2}$ stored seeds, $1 \mathrm{~T}_{2}$ shows $24 \%$ and $3 \mathrm{~T}_{2}$ shows $22 \%$ enhanced germination compared to control but $6 \mathrm{~T}_{2}$ didn't show sustained germination acceleration efficiency i.e. $\mathrm{O}_{3}$ treated seeds have more or less same or vaguely (negligibly) higher in germination frequency (9\%) compared to control seeds. We infer that the seeds loss its temperament when time prolongs and posses more or less normal germination efficiency as that of control. The seeds of $\mathrm{T}_{3}$ and $\mathrm{T}_{4}, \mathrm{O}_{3}$ treated for $30 \mathrm{~min}$ duration were found to be injured and when time prolongs the seeds recovered from the injury $\left(1 \mathrm{~T}_{3}=21 \%, 3 \mathrm{~T}_{3}=10 \% ; 1 \mathrm{~T}_{4}=50 \%, 3 \mathrm{~T}_{4}=\right.$ $43 \%$, and $6 \mathrm{~T}_{4}=37 \%$ ) and show enhanced germination $\left(6 \mathrm{~T}_{3}=21 \%\right)$ compared to initial stage. Therefore it was found that when time prolongs, $\mathrm{O}_{3}$ treatment loss its effect steadily and the germination efficiency of all the treatments are neither more or less same nor meagrely higher at six months after treatment. The data from our present study show that inducing dormancy could be break up by $\mathrm{O}_{3}$ treatment to the seeds resulted in an oxidative stress, which allows the seeds to germinate. It now appears more and more clear that ROS would play a key signalling role in the achievement of major events of seed life, such as germination or dormancy release.

In developing or germinating seeds, the active mitochondria are probably one of the major sources of ROS, generating superoxide, and subsequently $\mathrm{H}_{2} \mathrm{O}_{2}$ [23]. In seeds of some species, such as tobacco, tomato, pepper or Arabidopsis, germination is constraint by the micropylar endosperm, which covers the radicle tip [24]. Germination can proceed if the mechanical resistance imposed by the endosperm decreases to such a level that radicle can protrude through the weakened tissues. The $\mathrm{GA}_{3} / \mathrm{ABA}$ ratio is the most important hormone factor, which promote germination in seeds and led to improved germination performance [25]. This endosperm weakening is under the regulation of abscissic acid (ABA) and gibberellic acid (GA) and several hydrolases have been suspected to contribute to cell-wall loosening [26]. There is an increasing bundle of evidence suggesting that ROS would play a key role in this phenomenon and it has been proposed that they would be involved in cell wall loosening in growing tissues. Therefore, in order to examine the cause of $\mathrm{O}_{3}$ treatments on seed germination, $\mathrm{ABA}$ contents were analyzed (Table 2). Among the treatments, $\mathrm{T}_{2}$ treatment significantly reduced ( 5 fold) the ABA level in seeds compared to other treatments $T_{1}$ (1 fold), $T_{3}(2$ fold) and $\mathrm{T}_{4}$ (below 1 fold). The results revealed that the ABA levels were drastically reduced compared to ma- tured control seeds (Table 2).

There are also antagonistic effects of ABA and ethylene on dormancy and germination. Stimulation of ethylene synthesis by environmental stresses, such as $\mathrm{O}_{3}$, UV irradiation, and wounding, involve generation of reactive oxygen species [27]. Some responses of plant tissue to $\mathrm{O}_{3}$ fumigation may be due to active production of ethylene by the injured tissue [28]. Tomato, tobacco, and bean plants treated with $\mathrm{O}_{3}$ had increased rates of ethylene production [29]. Ethylene may promote germination by interfering with the ABA action on seed dormancy and/or maintenance of dormancy [30]. In some species, such as sunflower, ethylene can break seed dormancy [31]. Several components of the ethylene signal transduction have been identified and their signaling pathway has been characterized [32]. Ethylene signal transduction mutant studies highlight the interaction between ABA and ethylene signaling suggesting that ethylene suppresses dormancy by inhibiting ABA action [32]. The results from our study also confirm that the $\mathrm{O}_{3}$ treatment suppresses the ABA level significantly which may be due to the association of ethylene.

The elicitation of $\mathrm{GA}_{3}$ at mild concentration of $\mathrm{O}_{3}$ was observed [33], whereas, no statistically significant differences were found in the $\mathrm{GA}_{3}$ levels between the controls and the needles of trees which were treated with increased levels of $\mathrm{O}_{3}$. Similarly, from the results of our study it is anticipated that the generation of mild concentration of $\mathrm{O}_{3}\left(\mathrm{~T}_{1}\right.$ and $\left.\mathrm{T}_{2}\right)$ on the seeds could elicit higher level of $\mathrm{GA}_{3}$ rather than the other treatments $\left(\mathrm{T}_{3}\right.$ and $\left.\mathrm{T}_{4}\right)$ (Table 1).

On the one hand, there exists evidence suggesting that hydrogen peroxide alleviates seed dormancy. It was already reported that $\mathrm{H}_{2} \mathrm{O}_{2}$ reverse the inhibitory effect of ABA upon endosperm rupture, underlining the cross talk between these two compounds [34]. Antioxidants which

Table 2. Effect of ozone treatments on ABA content of mature tomato seeds.

\begin{tabular}{ccc}
\hline S.No & Treatments & ABA content ng·seed $^{\mathbf{- 1}}$ \\
\hline 1. & $\mathrm{C}$ & $1.8 \pm 0.2$ \\
2. & $\mathrm{~T}_{1}$ & $0.8 \pm 0.1$ \\
3. & $\mathrm{~T}_{2}$ & $0.3 \pm 0.0$ \\
4. & $\mathrm{~T}_{3}$ & $0.6 \pm 0.0$ \\
5. & $\mathrm{~T}_{4}$ & $0.9 \pm 0.0$ \\
\hline
\end{tabular}

The seeds were extracted at harvest (nondried) and each value in the data represent the mean of three experiments with ten replications each $(n=3)$. $\mathrm{T}_{1}=0.001 \mathrm{~g} \mathrm{O}_{3} \mathrm{~g}^{-1}$ seeds, $\mathrm{T}_{2}=0.01 \mathrm{~g} \mathrm{O}_{3} \mathrm{~g}^{-1}$ seeds, $\mathrm{T}_{3}=0.1 \mathrm{~g} \mathrm{O}_{3} \mathrm{~g}^{-1}$ seeds and $\mathrm{T}_{4}=1 \mathrm{~g} \mathrm{O}_{3} \mathrm{~g}^{-1}$ seeds were performed in the sterilized-diffusers for a time duration of 20 mins. While for the control (C) tomato seeds, charcoal filtered air (Cl-F) were passed. 
act as ROS scavenger in seed biology play a very important role in the growth processes occurring at early embryogenesis during seed development, participate in the mechanisms underlying radicle protrusion during seed germination and seed aging [35,36]. Exogenous $\mathrm{H}_{2} \mathrm{O}_{2}$ stimulates the germination of dormant seeds of barley, Fontaine et al. 1994; rice, [37] apple [38] and tomato [20]. Treatment of dormant barley seeds with hydrogen peroxide results in a decrease in endogenous ABA level [39] and alleviation of apple embryo dormancy by cyanide induces a simultaneous increase in $\mathrm{H}_{2} \mathrm{O}_{2}$ level and decrease in ABA content [38] $\mathrm{H}_{2} \mathrm{O}_{2}$ promoted seed germination in a dose-dependent manner as did respiratory inhibitors, indicating that $\mathrm{H}_{2} \mathrm{O}_{2}$ itself possibly promotes seed germination rather than $\mathrm{O}_{2}$ [40]. Therefore, in the present study, it is predicted that $\mathrm{H}_{2} \mathrm{O}_{2}$ activity in tomato endosperm would have greatly enhanced when the tissue was rupture, or wounded by the generation of $\mathrm{O}_{3}$ which results in the radicle penetration through the micropylar endosperm.

In general, the reaction of $\mathrm{O}_{3}$ on the surface of seeds takes place by way of a gas-solid type interchange, followed by diffusion within the structure. Among the possible interplay between ROS and plant hormones, the relationship between $\mathrm{H}_{2} \mathrm{O}_{2}$ and $\mathrm{ABA}$ appears as the most probable. Oxidative stress accelerates the accumulation of $\mathrm{H}_{2} \mathrm{O}_{2}$ in seeds. The hypothesis shown postulates that ROS play a central role with hormones and particularly $\mathrm{ABA}$, in dormancy release and germination completion. After treatment there is an accumulation of ROS by nonenzymatic ROS production. This accumulation might reduce ABA level and/or block ABA signalling, stimulate GA and ethylene signalling, modify redox status and downstream events and alter protein function through oxidative modifications.

The present work constitutes the basis for the future invention that it is possible to improve the germination properties and/or the growth of seedlings by treatment with $\mathrm{O}_{3}$, preferably produced from vector gases, without calling on an additional oxidizing agent, and with the treatment being relatively short in duration, ease in handling at very low cost. In general it is authenticated that, the person skilled in the art will find it relatively easy to determine the optimum conditions for implementation of the process.

\section{REFERENCES}

[1] W. E. Finch Savage, C. S. Cadman, P. E. Toorop, J. R. Lynn and H.W. Hilhorst, "Seed Dormancy Release in Arabidopsis Cvi by Dry after-Ripening, Low Temperature, Nitrate and Light Shows Common Quantitative Patterns of Gene Expression Directed by Environmentally Specific Sensing," Plant Journal, Vol. 51, No. 1, 2007 , pp. 60-78. doi:10.1111/j.1365-313X.2007.03118.X

[2] S. Penfield, E. M. Josse, R. Kannangara, A. D. Gilday, K. J. Halliday and I. A. Graham, "Cold and Light Control Seed Germination through the bHLH Transcription Factor SPATULA," Current Biology, Vol. 15, No. 22, 2005, pp. 1998-2006. doi:10.1016/j.cub.2005.11.010

[3] M. Koornneef, L. Bentsink and H. Hilhorst, "Seed Dormancy and Germination," Current Opinion Plant Biology, Vol. 5, No. 1, 2002, pp. 33-36. doi:10.1016/S1369-5266(01)00219-9

[4] R. Mittler, S. Vanderauwera, M. Gollery and F. Van Breusegem, "Reactive Oxygen Gene Network of Plants," Trends in Plant Science, Vol. 9, No. 10, 2004, pp. 490-498. doi:10.1016/j.tplants.2004.08.009

[5] K. Apel and H. Hirt, "Reactive Oxygen Species: Metabolism, Oxidative Stress, and Signal Transduction," Annual Review of Plant Biology, Vol. 55, No. 1, 2004, pp. 373399. doi:10.1146/annurev.arplant.55.031903.141701

[6] N. Sudhakar, D. Nagendra-Prasad, N. Mohan and K. Murugesan, "Induction of Systemic Resistance in Lycopersicon esculentum cv. PKM1 (tomato) against Cucumber Mosaic Virus by Using Ozone," Journal of Virological Methods, Vol. 139, No. 1, 2007, pp. 71-77. doi:10.1016/j.jviromet.2006.09.013

[7] N. Sudhakar, D. Nagendra-Prasad, N. Mohan and K. Murugesan, "Effect of Ozone on Induction of Resistance in Rhinacanthus nasutus (L.) Kurz. against Acute Ozone Exposure," Turkish Journal of Botany, Vol. 31, No. 2, 2007, pp. 135-141.

[8] D. Nagendra-Prasad, N. Sudhakar, K. Murugesan and N. Mohan, "Application of Ozone on Induction of Resistance in Vigna unguiculata cv. Co 6, against Fusarium wilt," Archives of Phytopathology and Plant Protection, Vol. 42, No. 7, 2009, pp. 633-642.

[9] P. Y. Bruice, "Organic Chemistry," 3rd Edition, Prentice-Hall, Upper Saddle River, 2001.

[10] C. Bailly, "Active Oxygen Species and Antioxidants in Seed Biology," Seed Science Research, Vol. 14, No. 2, 2004, pp. 93-107. doi:10.1079/SSR2004159

[11] H. El-Maarouf-Bouteau and C. Bailly, "Oxidative Signaling in Seed Germination and Dormancy," Plant Signaling \& Behavior, Vol. 3, No. 3, 2008, pp. 175-182. doi:10.4161/psb.3.3.5539

[12] M. B. McDonald, "Seed Deterioration: Physiology Repair and Assessment," Seed Science and Technology, Vol. 27, No. 1, 1999, pp. 177-237.

[13] P. Bucharov and T. Gantcheff, "Influence of Accelerated and Natural Aging on Free Radical Levels in Soybean Seeds," Physiologia Plantarum, Vol. 60, No. 1, 1984, pp. 53-56. doi:10.1111/j.1399-3054.1984.tb04248.x

[14] G. A. F. Hendry, "Oxygen, Free Radical Processes and Seed Longevity," Seed Science Research, Vol. 3, No. 3, 1993, pp. 141-153. doi:10.1017/S0960258500001720

[15] K. Oracz, H. El-Maarouf Bouteau, J. M. Farrant, K. Cooper, M. Belghazi, C. Job, D. Job, F. Corbineau and C. Bailly, "ROS Production and Protein Oxidation as a 
Novel Mechanism for Seed Dormancy Alleviation," Plant Journal, Vol. 50, No. 3, 2007, pp. 452-465. doi:10.1111/j.1365-313X.2007.03063.x

[16] H. El-Maarouf Bouteau, C. Job, D. Job, F. Corbineau and C. Bailly, "ROS Signaling in Seed Dormancy Alleviation," Plant Signaling \& Behavior, Vol. 2 No. 5, 2007, 362-364.

[17] ISTA, "Rules for Seed Testing Assoc, Norway," Seed Science and Technology, Vol. 4, 1976, pp. 2-49.

[18] E. Vermeer, E. Knegt and J. Bruinsma, "Determination of Abscisic Acid in Small Amounts of Plant Material," Journal of Chromatography A, Vol. 404, No. 2, 1987, pp. 346-351. doi:10.1016/S0021-9673(01)86875-8

[19] H. El-Maarouf-Bouteau and C. Bailly, "Oxidative Signaling in Seed Germination and Dormancy," Plant Signaling \& Behavior, Vol. 3, No. 3, 2008, pp. 175-182.

[20] Y. Morohashi, "Peroxidase Activity Develops in the Micropylar Endosperm of Tomato Seeds Prior to Radicle Protrusion," Journal of Experimental Botany, Vol. 53, No. 374, 2002, pp. 1643-1650. doi:10.1093/jxb/erf012

[21] P. Schopfer, C. Plachy and G. Frahry, "Release of Reactive Oxygen Intermediates (Superoxide Radicals, Hydrogen Peroxide, and Hydroxyl Radicals) and Peroxidase in Germinating Radish Seeds Controlled by Light, Gibberellin, and Abscisic Acid," Plant Physiology, Vol. 125, No. 4, 2001, pp. 1591-1602. doi:10.1104/pp.125.4.1591

[22] G. Sarath, G. Hou, L. M. Baird and R. B. Mitchell, "Reactive Oxygen Species, ABA and nitric Oxide Interactions on the Germination of Warm-Season C(4)-Grasses," Planta, Vol. 226, No. 3, 2007, pp. 697-708.

[23] G. Noctor, R. De Paepe and C. H. Foyer, "Mitochondrial Redox Biology and Homeostasis in Plants," Trends in Plant Science, Vol. 12, No. 3, 2007, pp. 125-134. doi:10.1016/i.tplants.2007.01.005

[24] W. E. Finch-Savage and G. Leubner-Metzger, "Seed Dormancy and the Control of Germination," New Phytology, Vol. 171, No. 3, 2006, pp. 501-523.

[25] M. M. EL-Araby, S. M. A. Moustafa, A. I. Ismail and A. Z. A. Hegaz, "Hormone and Phenol Levels during Germination and Osmopriming of Tomato Seeds, and Associated Variations in Protein Patterns and Anatomical Seed Features," Acta Agronomica Hungarica, Vol. 54, No. 4, 2006, pp. 441-457.

[26] G. Leubner-Metzger, "Beta-1,3-Glucanase Gene Expression in Low-Hydrated Seeds as a Mechanism for Dormancy Release during Tobacco after-Ripening," Plant Journal, Vol. 41, No. 1, 2005, pp. 133-145.

[27] S. L. Surplus, B. R. Jordan, A. M. Murphy, J. P. Carr, B. Thomas and S. A. H. Mackerness, "Ultraviolet-B Induced Responses in Arabidopsis Thaliana: Role of Salicylic Acid and Reactive Oxygen Species in the Regulation of Transcripts Encoding Photosynthetic and Acidic Pathogenesis Related Proteins," Plant Cell and Environment, Vol. 21, No. 7, 1998, pp. 685-694. doi:10.1046/j.1365-3040.1998.00325.x

[28] L. E. Craker, "Ethylene Production from $\mathrm{O}_{3}$ Injured
Plants," Environmental Pollution, Vol. 1, No. 4, 1971, 299-304. doi:10.1016/0013-9327(71)90022-X

[29] H. J. Stan and S. Schicker, "Effect of Repetitive Ozone Treatment on Bean Plants-Stress Ethylene Production and Leaf Necrosis," Atmospheric Environment, Vol. 16, No. 9, 1982, pp. 2267-2270. doi:10.1016/0004-6981(82)90298-0

[30] M. Ghassemian, E. Nambara, S. Cutler, H. Kawaide, Y. Kamiya and P. McCourt, "Regulation of Abscisic Acid Signalling by the Ethylene Response Pathway in Arabidopsis," Plant Cell, Vol. 12, No. 7, 2000, pp. 1117-1126.

[31] F. Corbineau, S. Bagniol and D. Côme, "Sunflower (Helianthus annuus L.) Seed Dormancy and Its Regulation by Ethylene," Israel Journal of Botany, Vol. 39, No. 4-6, 1990, pp. 313-325.

[32] B. Kucera, M. A. Cohn and G. Leubner-Metzger, "Plant Hormone Interactions during Seed dormancy Release and Germination," Seed Science Research, Vol. 15, No. 4, 2005, pp. 281-307. doi:10.1079/SSR2005218

[33] P. Schneider, K. Horn, R. Lauterbach and B. Hock, "Influence of Ozone and Acid Mist on the contents of Gibberellic Acid $\left(\mathrm{GA}_{3}\right)$ in Spruce Needles (Picea abies) (L.) Karst," Environmental Pollution, Vol. 64, No. 3-4, 1990, pp. 347-351. doi:10.1016/0269-7491(90)90056-I

[34] K. Müller, B. Heß and G. Leubner-Metzger, "A Role for Reactive Oxygen Species in Endosperm Weakening," In: S. Adkins, S. Ashmore and S. Navie, Eds., Seeds: Biology, Development and Ecology, CAB International, Wallingford, 2007, pp. 287-295.

[35] C. Bailly, "Active Oxygen Species and Antioxidants in Seed Biology," Seed Science Research, Vol. 14, No. 2, 2004, pp. 93-107. doi:10.1079/SSR2004159

[36] S. Kibinza, D. Vinel, D. Come, C. Bailly and F. Corbineau, "Sunflower Seed Deterioration as Related to Moisture Content during Ageing, Energy Metabolism and Active Oxygen Species Scavenging," Physiologia Plantarum, Vol. 128, No. 3, 2006, pp. 496-506. doi:10.1111/j.1399-3054.2006.00771.x

[37] M. E. B. Naredo, A. B. Juliano, B. R. Lu, F. De Guzman and M. T. Jackson, "Responses to Seed Dormancy-Breaking Treatments in Rice Species (Oryza L.)," Seed Science and Technology, Vol. 26, No. 3, 1998, pp. 675-689.

[38] R. Bogatek, H. Gawrońska and K. Oracz, "Involvement of Oxidative Stress and ABA in CN-Mediated Elimination of Embryonic Dormancy in Apple," In: G. Nicolas, K. J. Bradford, D. Come and H. W. Pritchard, Eds., The Biology of Seeds-Resent Research Advances, CABI, Wallingford, 2003, pp. 211-216.

[39] M. Wang, R. M. van der Meulen, K. Visser, H. P. Van Schaik, B. Van Duijn and A. H. de Boer, "Effects of Dormancy-Breaking Chemicals on ABA Levels in Barley Grain Embryos," Seed Science Research, Vol. 8, No. 2, 1998, pp. 129-137. doi:10.1017/S0960258500004025

[40] K. Ogawa and M. Iwabuchi, "A Mechanism for Promoting the Germination of Zinia elegans Seeds by Hydrogen Peroxide," Plant Cell Physiology, Vol. 42, No. 3, 2001, pp. 286-291. doi:10.1093/pcp/pce032 